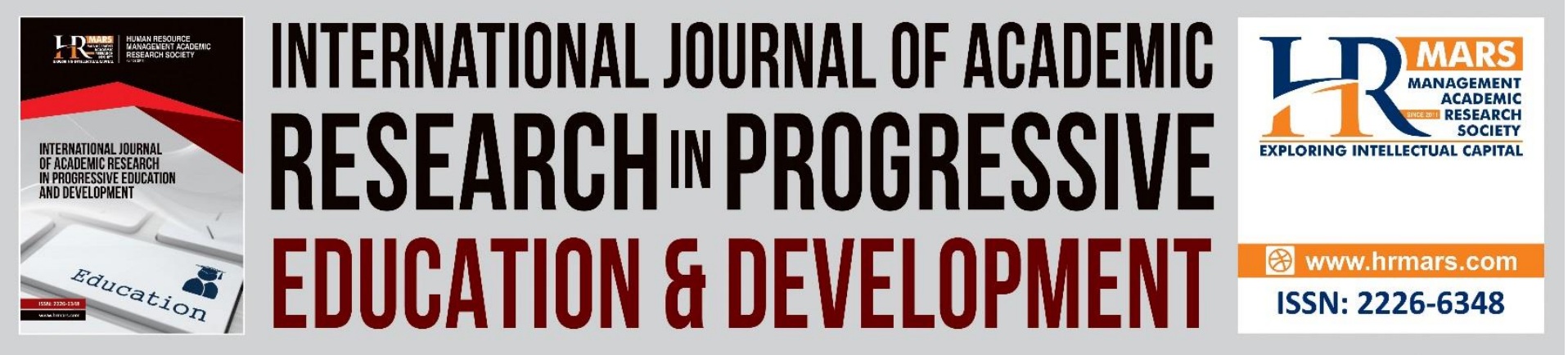

\title{
Understanding the Antecedents of Emotional Well-Being among University Students: Do Personality Traits Make a Difference?
}

Mohd Aidil Riduan Awang Kader, Nurul Nadia Abd Aziz, Suhanom Mohd Zaki, Musramaini Mustapha, Zaidatul Nadiah Abu Yazid

To Link this Article: http://dx.doi.org/10.6007/IJARPED/v11-i1/12182

DOI:10.6007/IJARPED/v11-i1/12182

Received: 05 November 2021, Revised: 08 December 2021, Accepted: 05 January 2022

Published Online: 21 January 2022

In-Text Citation: (Kader et al., 2022)

To Cite this Article: Kader, M. A. R. A., Aziz, N. N. A., Zaki, S. M., Mustapha, M., \& Yazid, Z. N. A. (2022). Understanding the Antecedents of Emotional Well-Being among University Students: Do Personality Traits Make a Difference? International Journal of Academic Research in Progressive Education and Development, 11(1), 771-784.

Copyright: (C) 2022 The Author(s)

Published by Human Resource Management Academic Research Society (www.hrmars.com)

This article is published under the Creative Commons Attribution (CC BY 4.0) license. Anyone may reproduce, distribute, translate and create derivative works of this article (for both commercial and non-commercial purposes), subject to full attribution to the original publication and authors. The full terms of this license may be seen

at: http://creativecommons.org/licences/by/4.0/legalcode

\section{Vol. 11(1) 2022, Pg. 771 - 784}

Full Terms \& Conditions of access and use can be found at http://hrmars.com/index.php/pages/detail/publication-ethics 


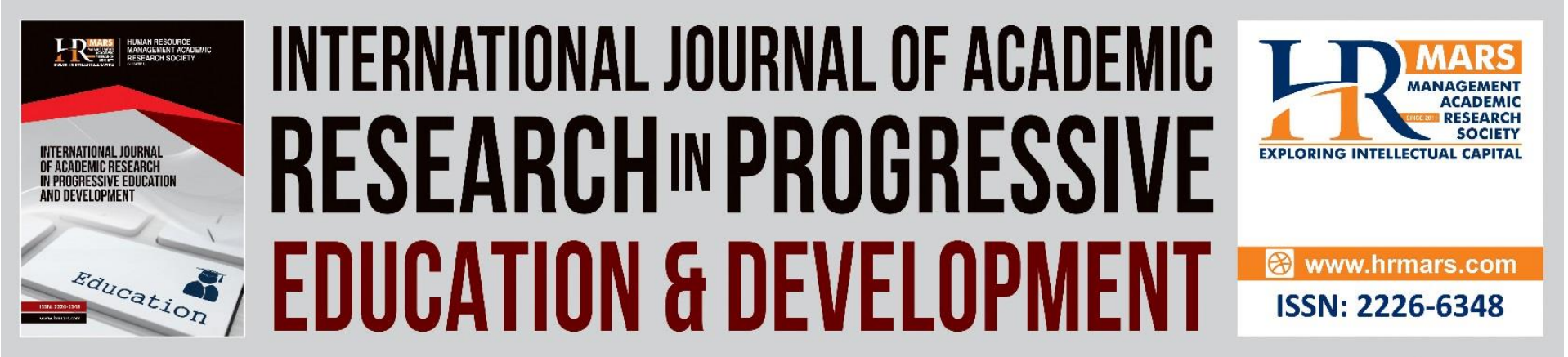

\title{
Understanding the Antecedents of Emotional Well-Being among University Students: Do Personality Traits Make a Difference?
}

\author{
Mohd Aidil Riduan Awang Kader ${ }^{1}$, Nurul Nadia Abd Aziz², \\ Suhanom Mohd Zaki ${ }^{1}$, Musramaini Mustapha ${ }^{1}$, Zaidatul Nadiah \\ Abu Yazid ${ }^{2}$ \\ ${ }^{1}$ Faculty of Business and Management, Universiti Teknologi MARA Pahang, \\ Jengka Campus, 26400 Bandar Pusat Jengka, Pahang, Malaysia, ${ }^{2}$ Faculty of Business and \\ Management, Universiti Teknologi MARA Pahang, Raub Campus, 27600 Raub, Pahang, \\ Malaysia \\ Email: aidilriduan@uitm.edu.my,suhanom@uitm.edu.my,musra_08@uitm.edu.my, \\ nurul_nadia@uitm.edu.my, zaidhea@uitm.edu.my
}

\begin{abstract}
Emotional well-being has been shown to be influenced by personality traits. However, little research has been done into how personality traits affect the relationship between actual use and emotional well-being. Since lecturers may develop a variety of pedagogical methods to ensure the effectiveness of the teaching and learning process during the Covid-19 pandemic, it is important to understand how the different personality traits of students may improve or weaken the relationship between actual use and emotional well-being. Hence, this study aims to examine the predicting factors that contribute to online learning acceptance among undergraduates, and to investigate the moderating effect of personality traits in the relationship between actual use of online learning and emotional well-being. In order to explore factors that affect students' emotional well-being, this study used and extended the Technology Acceptance Model (TAM) by incorporating emotional well-being as a new variable. An online survey was conducted among 247 respondents at Universiti Teknologi MARA Pahang who are currently undergoing online learning. SEM-AMOS was employed to test the developed hypotheses. Except for the relationship between perceived usefulness and attitude towards using online learning, all hypothesis showed significant results. In addition, personality traits moderate the relationship between actual use and emotional well-being. This study can help university administrators and educators identify effective online learning resources that will make it easier for undergraduates to use the platforms, reduce stress, and enhance their emotional well-being.
\end{abstract}

Keywords: Emotional Well-being, Online Learning, Personality Traits, TAM. 


\section{Introduction}

E-learning, distance learning, and even virtual learning are all terms used to describe online learning. It is a technical platform that allows students to learn at their own speed and time using the Internet (Solangi et al., 2018). COVID-19 has prompted the entire world to briefly switch to full distance learning. Online learning was implemented in tertiary education due to the outbreak of COVID-19 which caused a decline in face-to-face teaching and learning. Teaching platforms such as Zoom, WebEx, Microsoft Teams, Google Meet, Telegram, WhatsApp, and many more enable students to learn anywhere with a flexible schedule and environment, convenience and accessibility, customization and outsourcing, and costeffectiveness. Irrespective of the benefits of online learning for students and institutions, there is also a need to assess students' emotional well-being when it comes to online learning. There is still a lack of understanding of how people adapt and react to the new standard of life, which includes educational activities. As a result, the emotional responses of students to online learning during a pandemic are unclear. Most university students are struggling in managing their time for studying and completing assignments to meet deadlines, and they worry that online learning will affect their academic performance which will lead to depression, loss of motivation, and loss of interest in learning. Internet access troubles, newness with the platforms and systems used, teaching mediums that are not user-friendly, and lack of support from families and lecturers; these points demonstrate the importance of examining students' mental well-being when it comes to online learning. This means that if emotional well-being problems are not resolved immediately, they can trigger emotional instability, which can lead to negative consequences such as stress, depression, low selfesteem, and weak self-efficacy because of online learning difficulties (Saade et al., 2017).

Personality traits have been shown to have a significant impact on emotional wellbeing. However, there is a lack of studies that investigate that personality traits moderate the relationship between actual use and emotional well-being. It is important to understand the difference as students may strengthen or weaken the relationship between actual use and emotional well-being since lecturers may create a variety of pedagogical methods to accommodate students of various personality traits in order to ensure the effectiveness of the teaching and learning process during the COVID-19 pandemic. This research used and expanded the Technology Acceptance Model (TAM) by adding emotional well-being as a new variable in order to investigate factors that influence students' emotional well-being. TAM is the most used model of technology acceptance and usage, which is determined by perceived ease of use, perceived utility, and attitude. TAM is a term that refers to important behaviours. Therefore, the objectives of this study are: 1) to examine the predicting factors that contribute to online learning acceptance among undergraduates, and 2) to investigate the moderating effect of personality traits in the relationship between actual use of online learning and emotional well-being. This research is expected to aid university administrators and educators in identifying the appropriate online learning tools that will make it easier for undergraduates to use the platforms, alleviate stress, and improve their emotional wellbeing.

\section{Literature Review Underpinning Theory}

The Technology Acceptance Model (TAM) was introduced by Davis (1989), as depicted in Figure 1. This model aims to explain user intentions in using technology and the subsequent usage behaviour. TAM has become one of the prominent models employed to explain the 
adoption and usage of technology by individuals. This model focuses on two theoretical constructs; perceived usefulness and perceived ease of use. According to Davis (1989), perceived usefulness is the "degree to which a person believes that using a particular system would enhance his or her performance", while perceived ease of use refers to "the degree to which a person believes that using a particular system would be free of effort" (Davis, 1989). This means that when technology can benefit the user, and it is easy to use, the attitude towards using the technology will be positive, then the intention to use the technology will be higher which will lead to actual use. Many researchers have extended the original model of TAM to investigate the factors determining the success of online learning implementation in Saudi Arabia (Solangi et al., 2018) and to examine the attitude towards the use of multimedia in Taiwan (Weng et al., 2018). Therefore, this study has introduced a new variable, namely, emotional well-being as an extension of the existing TAM.

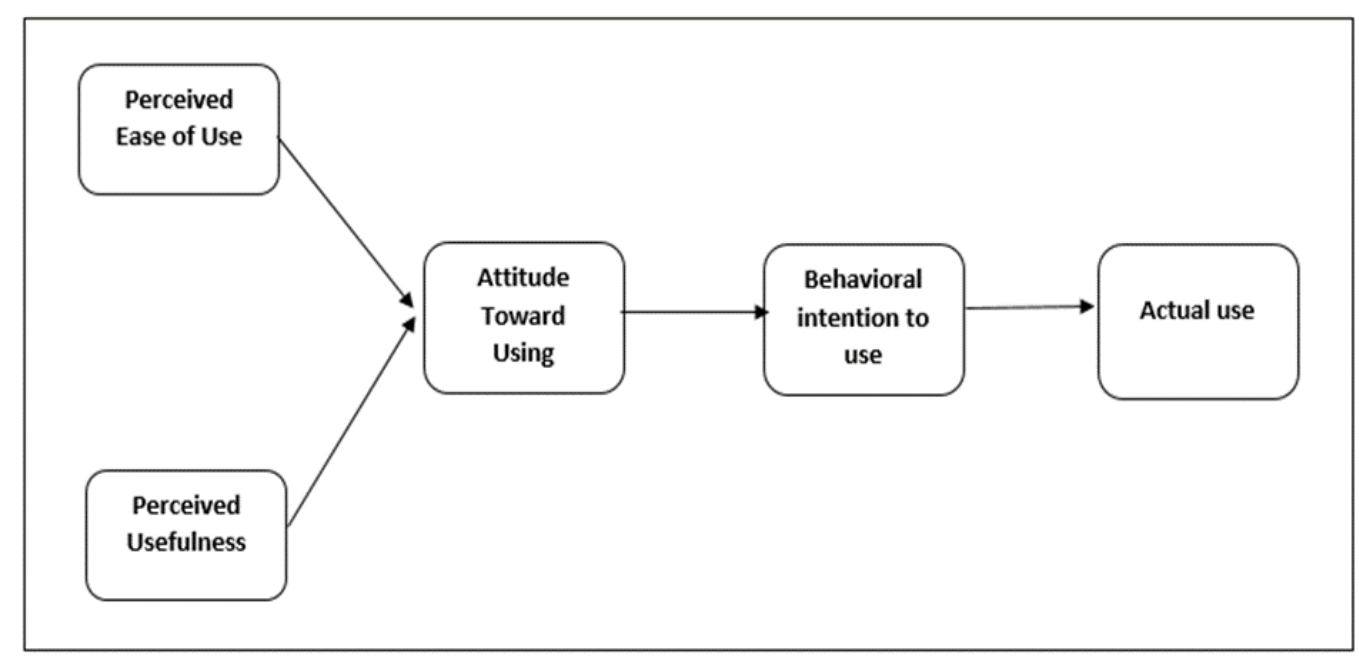

Fig. 1 Original model of Technology Acceptance Model by Davis (1989)

\section{Perceived Usefulness}

According to Davis (1989), perceived usefulness is the degree to which a person believes that using a particular system would enhance his or her job performance. The perceived usefulness would improve students' attitudes toward their learning experiences of online learning and allow them to use the Internet for the teaching and learning process. Kerzic et al. (2019) found that when teachers are involved in their tasks and students have a positive attitude in the virtual classroom, online learning is considered to be beneficial. Alsabawy et al. (2016) investigated the impact of IT infrastructure services and e-learning system quality on perceived usefulness among 720 Australian university students. They discovered a connection between perceived usefulness and the use of an e-learning method. As a result, it is hypothesised that:

$\mathrm{H} 1$ : There is a significant relationship between perceived usefulness and attitude towards using online learning.

\section{Perceived Ease of Use}

The degree to which an individual assumes that using a particular system would be free of effort is referred to as perceived ease of use (Davis, 1989). Many previous studies looked into the connection between perceived ease of use and attitudes toward online learning. Farhan et al (2019) investigated 102 Canadian undergraduates and discovered a connection between perceived ease of use and students' attitudes toward using web 
programming languages to facilitate instructional communication in an online learning environment. Hussein (2017) discovered that perceived ease of use is a strong predictor of students' willingness to use online learning. Following the preceding statement, it is hypothesised that:

$\mathrm{H} 2$ : There is a significant relationship between perceived ease of use and attitude toward using online learning.

\section{Student Satisfaction}

In the context of online learning, students' satisfaction can be described as a shortterm attitude based on an evaluation of the online learning experience, programmes, and facilities provided to them. According to a study conducted by Menon et al. (2021) on 319 medical students in India, nearly half of them felt that attending class via online was less satisfying. This is in line with the study by Raheim (2021) which found that students faced technical obstacles that obstruct the remote learning process, such as computer issues, Internet connectivity issues, and distracting issues in online learning. This finding, however, contradicted the investigation by Yawson and Yamoah (2020) of 611 undergraduates in Ghana. They discovered that in a multi-generational undergraduate online learning environment, Generation $Z$ is more satisfied with online learning than Generations $X$ and $Y$, owing to their compatibility and reliance on computer technology. Therefore, it is hypothesized that:

H3: There is a significant relationship between student satisfaction and attitude towards online learning.

\section{Attitude}

Students' attitudes toward online learning, whether positive or negative, are reflected in their attitudes toward use. In Taiwan, Weng et al. (2018) discovered a significant relationship between attitude toward using and intention to use multimedia material in the teaching and learning process. Peytcheva-Forsyth et al. (2018) examined the attitudes of 590 university students in Bulgaria and discovered a relationship between online learning and distance education. Following the above argument, it is postulated that:

$\mathrm{H} 4$ : There is a significant relationship between attitude toward using and behavioural intention to use online learning.

\section{Behavioural Intention}

Almaiah and Alyoussef (2019) investigated the key factors affecting Saudi Arabian students' actual use of e-learning systems. The findings revealed that course design, course content support, course evaluation, and teacher characteristics have a substantial impact on e-learning system use. Wang et al. (2019) also discovered that computer self-efficacy and satisfaction have a significant impact on behavioural intentions to use online learning applications in their research. As a result, it is hypothesised that:

$\mathrm{H} 5$ : There is a significant relationship between behavioural intention to use online learning and actual use of online learning.

\section{Actual Use}

Previous studies have discovered that online education has a direct effect on human well-being including emotional. Porter and Donthu (2006) found that there is an association between actual Internet use and emotional well-being. In a study of 1377 undergraduates in 
Canada, Saade et al. (2017) examined the relationship between anxiety and performance in online courses. According to the findings, $30 \%$ of respondents tend to have some level of anxiety when taking online courses. On the other hand, innovation on the Internet brings benefits to human well-being when information communication technology (ICT) tools such as new applications in education cause students to better manage their online learning. Based on the above argument, it is postulated that:

H6: There is a significant relationship between actual use of online learning and emotional well-being.

\section{Personality Traits}

Bhagat et al. (2019) had classified personality traits into five categories, namely extraversion (ambitious, active, honest, and social), agreeableness (flexible, tolerant, amiability, and cooperative), conscientiousness (organised, efficient, precise, persistent and systematic), neuroticism (depressed, anxious, irritability, emotional, moodiness and insecure), and intellect/imagination (broad-minded and curious). They conducted a research on 208 Taiwanese university students and discovered that personality traits (conscientiousness and intellect/imagination) had a greater positive influence on students' impressions of online learning, while neuroticism had a strong negative impact on online course participants. Yu (2021) examined the impact of personality traits on online learning during the Covid-19 pandemic among 1152 respondents from a public university in China. The results of this study revealed that students with higher extraversion and agreeableness contributed to higher emotional well-being. Therefore, it is postulated that:

H7: Personality traits moderate the relationship between actual use and emotional well-being.

\section{Conceptual Framework}

In extending the previous study, this research investigated the relationships of perceived usefulness, perceived ease of use and students' satisfaction toward their attitude in using online learning. This research then verified the influence of the behavioural intention to use and actual use of online learning. Also, the actual use of online learning was tested to find out if it has a significant relationship with emotional well-being. Besides that, this research determined how the differences in personality traits could moderate the relationship between actual use and emotional well-being among respondents. The conceptual framework is depicted in Figure 2.

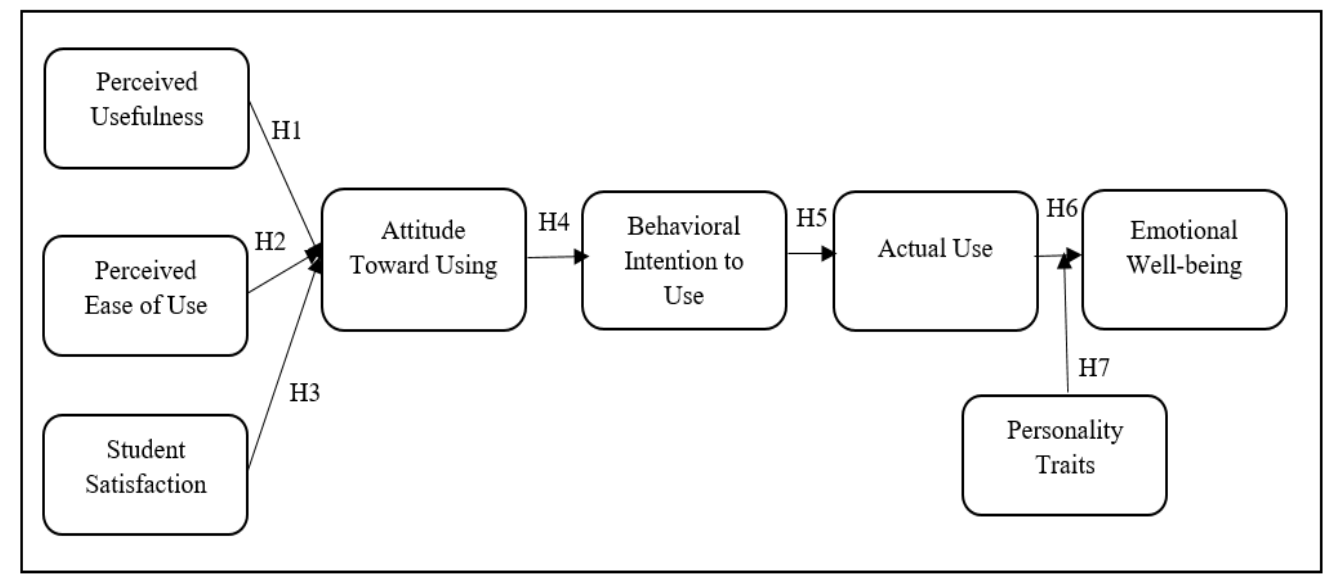

Fig. 2 Conceptual Framework 
DEVELOPMENT

Vol. 11, No. 1, 2022, E-ISSN: 2226-6348 ㄷ 2022 HRMARS

\section{Methodology}

A survey was conducted among the students of Universiti Teknologi MARA Pahang who are currently employing an online and distance learning concept during the occurrence of the Covid-19 pandemic. A set of questionnaires were distributed using Google Forms to the respective respondents and 247 students responded to the survey. The questionnaires were constructed from the established technology acceptances literature and adapted based on the intended research conducted in this study. The items measured in this study included perceived usefulness, perceived ease of use, student satisfaction, attitude toward using, behavioural intention to use, actual use and emotional well-being, and also a moderator of personality traits. A set of $\mathbf{4 0}$ measurement items from the technology acceptance literature was adopted and adapted to the specific context of this study on the acceptance and usage of online learning (Davis, 1989; Porter \& Donthu, 2006; Saade et al., 2017; and Weng et al., 2018). Each participant was asked to indicate their agreement and disagreement to each statement of the items using a ten-point Likert scale, ranging from 1 (strongly disagree) to 10 (strongly agree).

\section{Respondents Profile}

A total of 247 respondents was involved in this study, where 34 per cent of them were diploma students, and 66 per cent were Bachelor's degree students. Female students accounted for 74.5 per cent of the respondents, while the remaining 25.5 per cent were male students. Respondents aged between 18 and 21 years attained 76.9 per cent. In comparison, 23.1 per cent were respondents aged 22 years and above. In terms of the respondents' division, 51.4 per cent of the respondents were students from the Faculty of Business and Management, 25.5 per cent were students from the Faculty of Applied Sciences, and 22.7 per cent were students from the Faculty of Accountancy.

\section{Results and Discussion \\ Confirmatory Factor Analysis}

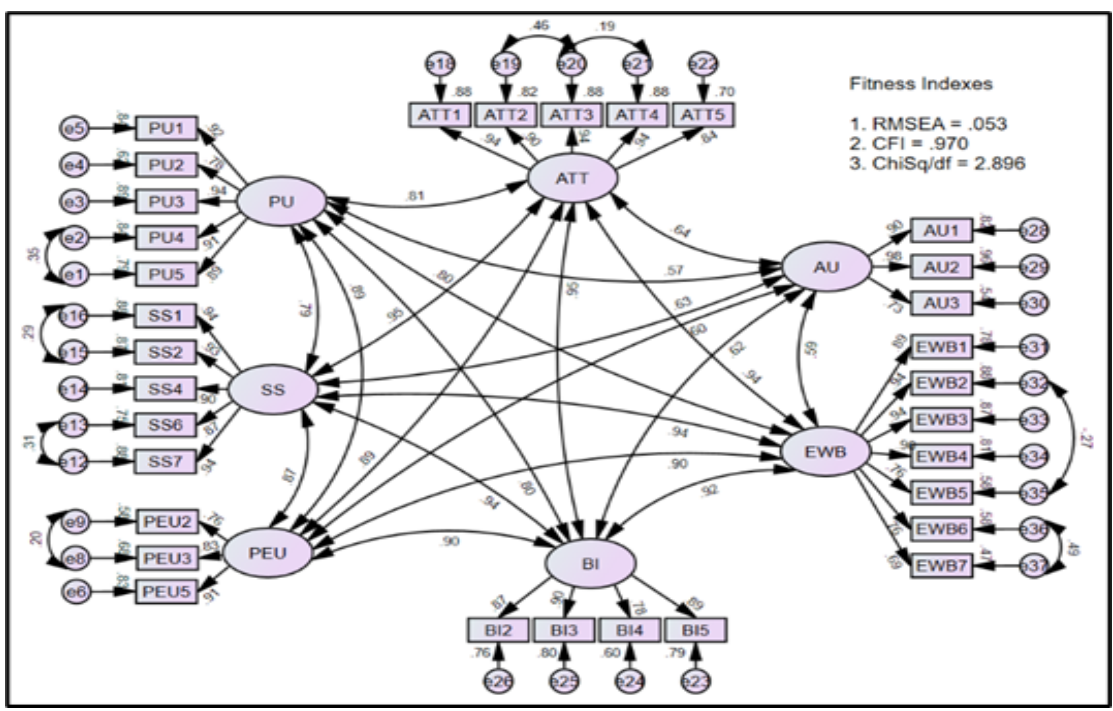

Fig. 3 The CFA Results 
Notes: $\mathrm{N}=460 ; \mathrm{PU}=$ Perceived Usefulness; $\mathrm{PEU}=$ Perceived Ease of Use; $\mathrm{SS}=$ Student Satisfaction; $\mathrm{ATT}=$ Attitude; $\mathrm{BI}=$ Behavioural Intention; $\mathrm{AU}=$ Actual Use; $\mathrm{EWB}=$ Emotional Well-Being

The CFA was run on the 32 items, and the 7-factor model fit the data well (RMSEA = $0.53, \mathrm{CFI}=0.970, \mathrm{ChiSq} / \mathrm{df}=2.896)$. The results indicate that this model displayed a reasonably good fit to the observed data.

\section{Structural Equation Modelling}

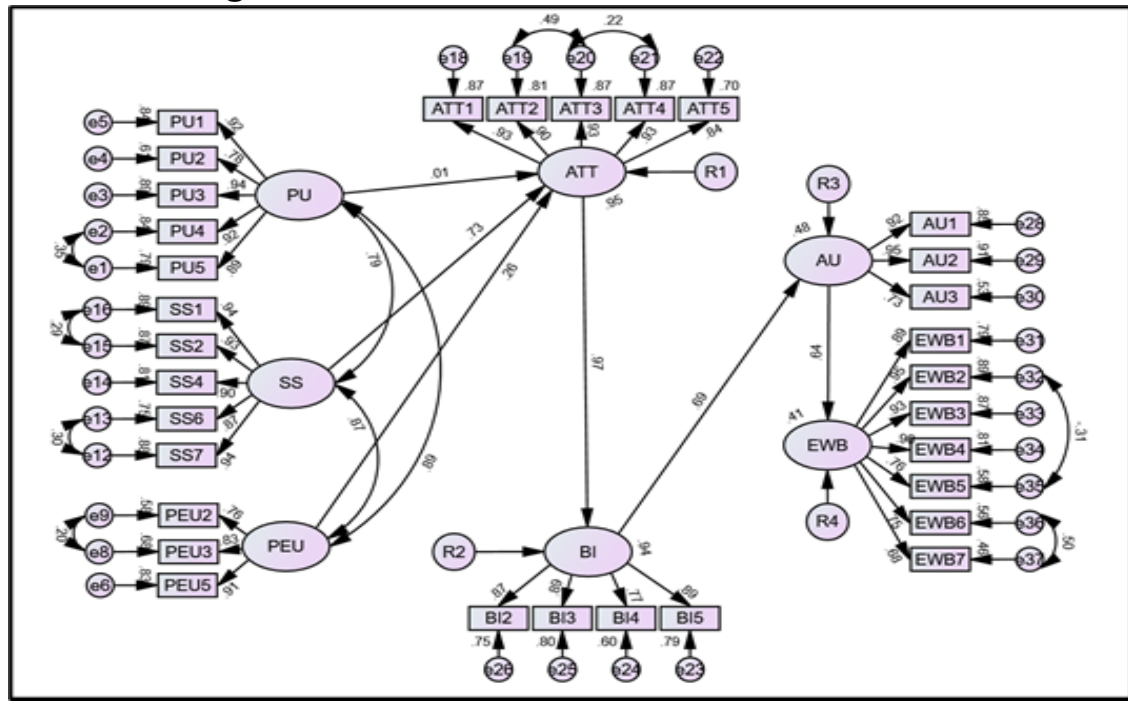

Fig. 4 The Standardised Path Coefficients (Direct Relationship)

Notes: $N=460 ; \mathrm{PU}=$ Perceived Usefulness; $\mathrm{PEU}=$ Perceived Ease of Use; $\mathrm{SS}=$ Student Satisfaction; $\mathrm{ATT}=$ Attitude; $\mathrm{BI}=$ Behavioural Intention; $\mathrm{AU}=$ Actual Use; $\mathrm{EWB}=$ Emotional Well-Being

Table 1. The Standardised Regression Weights and Its Significance

\begin{tabular}{|c|c|c|c|c|c|c|c|c|}
\hline & \multicolumn{3}{|c|}{ Paths } & Estimate & S.E. & C.R. & $\mathbf{P}$ & Results \\
\hline $\mathrm{H} 1$ & PU & $\rightarrow$ & ATT & .014 & .043 & .326 & .744 & Not significant \\
\hline $\mathrm{H} 2$ & PEU & $\rightarrow$ & ATT & .283 & .060 & 4.682 & $* * *$ & Significant \\
\hline H3 & SS & $\rightarrow$ & ATT & .672 & .034 & 19.699 & $* * *$ & Significant \\
\hline $\mathrm{H} 4$ & ATT & $\rightarrow$ & $\mathrm{BI}$ & .986 & .027 & 36.293 & $* * *$ & Significant \\
\hline H5 & $\mathrm{BI}$ & $\rightarrow$ & $\mathrm{AU}$ & .674 & .034 & 19.692 & $* * *$ & Significant \\
\hline H6 & $A U$ & $\rightarrow$ & EWB & .622 & .035 & 17.965 & $* * *$ & Significant \\
\hline
\end{tabular}

Notes: $\mathrm{N}=460 ; \mathrm{PU}=$ Perceived Usefulness; $\mathrm{PEU}=$ Perceived Ease of Use; $\mathrm{SS}=$ Student Satisfaction; $\mathrm{ATT}=$ Attitude; $\mathrm{BI}=$ Behavioural Intention; $\mathrm{AU}=$ Actual Use; $\mathrm{EWB}=$ Emotional Well-Being

As shown in Figure 4 and Table 1, all hypothesized relationships indicate a significant result except $\mathrm{H} 1$. The result of the study shows that there is no significant relationship between perceived usefulness and attitude toward using online learning. Therefore, $\mathrm{H} 1$ is rejected since $\beta=0.014, p>0.000$. This is due to the fact that since online learning is the main method of teaching and learning for all UiTM students during the COVID-19 pandemic, it can be concluded that perceived usefulness has little impact on students' attitudes toward using 
online learning. Despite the fact that students acknowledged the value of online learning, the majority of students denied that they have a positive attitude about it. This finding is inconsistent with the study by Alsabawy et al (2016) who found a positive relationship between perceived usefulness and attitude toward using online learning.

For $\mathrm{H} 2$, the perceived ease of use was significant to attitude with $\beta=0.283, \mathrm{p}=0.000$. The positive relationship means that the increase in students' perception towards the ease of use will increase their attitude towards online learning. This is because most of the respondents are Generation $Y$ who are the tech-savvy generation. Therefore, the deployment of various synchronous online learning platforms such as Google Meet and asynchronous online learning platforms such as Telegram and WhatsApp, are easily adopted by this generation. The result of this study complies with the studies of Farhan et al. (2019) and Hussein (2019), who determined that perceived ease of use and attitude towards using online learning has a significant relationship.

For $\mathrm{H} 3$, students' satisfaction was significant to attitude towards online learning ( $\beta=$ $.672, p=0.000)$. This positive relationship means that an increase in the students' satisfaction will increase students' attitude towards online learning. The flexibility of studying according to their own schedule and place may have resulted as satisfaction that led to a positive attitude. This finding was demonstrated through good student attendance, active interaction, accomplishment of assignments and assessments throughout the semesters affected by COVID-19. Satisfied students who learn through an online platform may show a positive behavioural response indicated by their positive attitude towards online learning. This result contradicts with a previous study by Menon et al. (2021) where students' satisfaction has an insignificant effect towards students' attitude in using the Internet and adopting online learning.

Next, for $\mathrm{H} 4$, attitude was significant to behavioural intention with $\beta=0.986, p=0.000$. This significant relationship emphasized that the students have a positive attitude and intention to use online learning in the future. Even after the COVID-19 pandemic has ended, most of the students will seriously consider using online learning if it still exists. This might be due to the benefits gained from online learning such as flexible schedule and environment, accessibility, convenience, and ease of use. Hence, most respondents claimed that they have the intention to use online learning as a future learning method. This result was in agreement with previous studies (Peytcheva-Forsyth et al., 2018; Weng et al., 2018) that found a significant relationship between techno-uncertainty and performance expectancy.

Meanwhile, for $\mathrm{H} 5$, behavioural intention was significant to the actual use of online learning $(\beta=0.674, p=0.000$ ). The positive relationship means the higher the behavioural intention, the higher the actual use of online learning. Besides that, actual use was significant to emotional well-being with $\beta=0.622$ and $p=0.000$. Therefore, $\mathrm{H} 6$ was also supported. This finding demonstrates that UITM students allocate a lot of time in conducting academic activities online including attending lectures, having discussions with other students in accomplishing assignments, taking quizzes, tests, and final assessments. This is due to the adoption of online learning as the main platform for teaching and learning during the COVID19 pandemic with many advantages that can be gained such as increased self-efficacy and enjoyment (Wang et al., 2019). This finding is similar to a previous study by Wang et al. (2019) who revealed that computer self-efficacy and enjoyment had a significant positive effect on undergraduates' behavioural intention in continuing their studies online. 
INTERNATIONAL JOURNAL OF ACADEMIC RESEARCH IN PROGRESSIVE EDUCATION AND

DEVELOPMENT

Vol. 11, No. 1, 2022, E-ISSN: 2226-6348 @ 2022 HRMARS

\section{Moderating Testing}

Table 2. Results of chi-square value and the number of degrees of freedom for constrained model and unconstrained model for the group of introvert students

\begin{tabular}{|c|c|c|c|c|c|c|c|c|c|c|}
\hline & Cons & ained mo & & & & Unce & strained $n$ & ode & & \\
\hline Model & $\begin{array}{l}\text { NPA } \\
\text { R }\end{array}$ & CMIN & DF & $\begin{array}{l}p- \\
\text { valu } \\
\text { e }\end{array}$ & $\begin{array}{l}\text { CMIN } \\
/ \\
\text { DF }\end{array}$ & $\begin{array}{l}\text { NPA } \\
\mathrm{R}\end{array}$ & CMIN & DF & $\begin{array}{l}p- \\
\text { valu } \\
e\end{array}$ & $\begin{array}{l}\text { CMIN } \\
/ \\
\text { DF }\end{array}$ \\
\hline $\begin{array}{l}\text { Default } \\
\text { model }\end{array}$ & 80 & $\begin{array}{l}1189.95 \\
2\end{array}$ & $\begin{array}{l}44 \\
8\end{array}$ & .000 & 2.656 & 81 & $\begin{array}{l}1176.72 \\
0\end{array}$ & $\begin{array}{l}44 \\
7\end{array}$ & .000 & 2.632 \\
\hline $\begin{array}{l}\text { Saturated } \\
\text { model }\end{array}$ & 528 & .000 & 0 & & & 528 & .000 & 0 & & \\
\hline $\begin{array}{l}\text { Independen } \\
\text { ce model }\end{array}$ & 32 & $\begin{array}{l}9208.11 \\
8\end{array}$ & $\begin{array}{l}49 \\
6\end{array}$ & .000 & $\begin{array}{l}18.56 \\
5\end{array}$ & 32 & $\begin{array}{l}9208.11 \\
8\end{array}$ & $\begin{array}{l}49 \\
6\end{array}$ & .000 & $\begin{array}{l}18.56 \\
5\end{array}$ \\
\hline
\end{tabular}

Table 3. Results of moderation test for the group of introvert students

\begin{tabular}{cccccc}
\hline & $\begin{array}{c}\text { Constrained } \\
\text { model }\end{array}$ & $\begin{array}{c}\text { Unconstrained } \\
\text { model }\end{array}$ & $\begin{array}{c}\text { Chi-square } \\
\text { difference }\end{array}$ & $\begin{array}{c}\text { Result of } \\
\text { moderation } \\
\text { test }\end{array}$ & Hypothesis \\
\hline $\begin{array}{c}\text { Chi-square } \\
\text { DF }\end{array}$ & $\begin{array}{c}1189.952 \\
448\end{array}$ & $\begin{array}{c}1176.720 \\
447\end{array}$ & $\begin{array}{c}13.232 \\
1\end{array}$ & Significant & Supported \\
\hline
\end{tabular}

Following that, the obtained data were grouped into (1) group of introverts, and (2) group of extroverts prior to the analysis for the testing of the moderating role of personality traits in the relationship between actual use and emotional well-being in this study. In particular, the participating students with a mean value of 5.99 and below for their personality traits were included in the group of introverts, while the remaining students (with a mean of below 6.00 for their personality traits) represented the group of extroverts. Referring to Table 2, the constrained model recorded a chi-square value (CMIN) of 1189.952 with a degree of freedom (DF) of 448, while the unconstrained model recorded a chi-square value of 1176.720 with DF of 447. As shown in Table 3, the difference in the chi-square value and DF between both models for the group of personality traits were 13.232 and 1, respectively. The difference in chi-square value $(13.232, \mathrm{DF}=1)$ was higher than the chisquare value of 3.84 ( $D F=1$ ). In other words, the result of the moderation test was significant for the group of introvert students. 
INTERNATIONAL JOURNAL OF ACADEMIC RESEARCH IN PROGRESSIVE EDUCATION AND

DEVELOPMENT

Vol. 11, No. 1, 2022, E-ISSN: 2226-6348 @ 2022 HRMARS

Table 4. Results of chi-square value and the number of degrees of freedom for constrained model and unconstrained model for the group of extrovert students

$$
\text { Constrained model Unconstrained model }
$$

\begin{tabular}{lllllllllll}
\hline Model & $\begin{array}{l}\text { NPA } \\
\mathrm{R}\end{array}$ & CMIN & DF & $\begin{array}{l}\mathrm{p}- \\
\text { valu } \\
\mathrm{e}\end{array}$ & $\begin{array}{l}\text { CMIN } \\
\text { /DF }\end{array}$ & $\begin{array}{l}\text { NPA } \\
\mathrm{R}\end{array}$ & CMIN & DF & $\begin{array}{l}\mathrm{p}- \\
\text { valu } \\
\mathrm{e}\end{array}$ & $\begin{array}{l}\text { CMIN } \\
\text { /DF }\end{array}$ \\
\hline $\begin{array}{l}\text { Default } \\
\text { model }\end{array}$ & 80 & $\begin{array}{l}1389.23 \\
2\end{array}$ & $\begin{array}{l}44 \\
8\end{array}$ & .000 & 3.101 & 81 & $\begin{array}{l}1359.75 \\
2\end{array}$ & $\begin{array}{l}44 \\
7\end{array}$ & .000 & 3.042 \\
\hline $\begin{array}{l}\text { Saturated } \\
\text { model }\end{array}$ & 528 & .000 & 0 & & & 528 & .000 & 0 & & \\
\hline $\begin{array}{l}\text { Independen } \\
\text { ce model }\end{array}$ & 32 & $\begin{array}{l}10328.5 \\
65\end{array}$ & 49 & 6 & .000 & $\begin{array}{l}20.82 \\
4\end{array}$ & 32 & $\begin{array}{l}10328.5 \\
65\end{array}$ & 49 & 6 \\
\hline
\end{tabular}

Table 5. Results of moderation test for the group of extrovert students

\begin{tabular}{lccccc}
\hline & $\begin{array}{c}\text { Constrained } \\
\text { model }\end{array}$ & $\begin{array}{c}\text { Unconstrained } \\
\text { model }\end{array}$ & $\begin{array}{c}\text { Chi-square } \\
\text { difference }\end{array}$ & $\begin{array}{c}\text { Result of } \\
\text { moderation } \\
\text { test }\end{array}$ & Hypothesis \\
\hline Chi-square & 1389.232 & 1359.752 & 29.480 & Significant & Supported \\
DF & 448 & 447 & 1 & &
\end{tabular}

On the other hand, for the group of extroverts (Table 4), the constrained model recorded a chi-square value (CMIN) of 1389.232 with DF of 448 while the unconstrained model recorded a chi-square value of 1359.752 with DF of 447. As shown in Table 5, the difference in chi-square value and DF between both models for the group of extroverts were 29.480 and 1 , respectively. Similarly, the result of the moderation test was significant for the group of extroverts since the obtained difference in chi-square value $(29.480$, DF $=1$ ) exceeded the chi-square value of 3.84 (DF = 1). Considering the obtained results for both groups of introverts and extroverts, partial moderation was demonstrated.

Table 6: The moderation effect of actual use on emotional well-being for the group of introvert students and group of extrovert students

\begin{tabular}{|c|c|c|c|c|c|c|c|c|}
\hline \multirow{2}{*}{$\begin{array}{l}\text { Group } \\
\text { Introvert } \\
\text { Students }\end{array}$} & \multicolumn{3}{|c|}{$\begin{array}{l}\text { Hypothesised } \\
\text { path }\end{array}$} & \multirow{2}{*}{$\begin{array}{c}\text { Estimate } \\
.469\end{array}$} & \multirow{2}{*}{$\begin{array}{l}\text { S.E. } \\
.053\end{array}$} & \multirow{2}{*}{$\begin{array}{c}\text { C.R. } \\
8.813\end{array}$} & \multirow{2}{*}{$\begin{array}{c}\begin{array}{c}p- \\
\text { value }\end{array} \\
.000\end{array}$} & \multirow{2}{*}{$\begin{array}{c}\text { Result } \\
\text { Significant }\end{array}$} \\
\hline & $A U$ & $\rightarrow$ & EWB & & & & & \\
\hline $\begin{array}{l}\text { Extrovert } \\
\text { Students }\end{array}$ & $A U$ & $\rightarrow$ & EWB & .633 & .059 & $\begin{array}{c}10.74 \\
6\end{array}$ & .000 & Significant \\
\hline
\end{tabular}

Notes: AU denotes actual use; EWB denotes emotional well-being.

Considering that the prior testing of the moderation effect of personality traits was conducted based on a non-parametric approach, this study ensued with the parametric testing of the moderation effect of personality trait, which specifically ascertained the significance of the moderation effect in the groups of introverts and extroverts. Referring to Table 6, the group of introverts produced a standardized parameter estimate of 0.469 ( $p=$ 0.000; significant), while the group of extroverts recorded a significant standardized 
parameter estimate of $0.633(p=0.000)$. Evidently, the influence of actual use on emotional well-being was more apparent in the extrovert group. Considering the significance of the standardized estimates, partial moderation was reaffirmed. This finding implies that actual use of online learning has a significant effect on the emotional well-being for both groups (introvert and extrovert), but the effect on extroverts is stronger than introverts (even though both are significant). Thus, $\mathrm{H} 7$ was supported. This result is similar with the study by $\mathrm{Yu}$ (2021) who found that personality traits moderate the relationship between actual use and emotional well-being.

\section{Conclusion}

The results from the study stated just one hypothesis out of five was found to be rejected, according to the study's findings. Hypothesis $\mathrm{H} 1$ was dismissed because perceived utility was shown to have no substantial impact on the attitude towards online learning. Since the effect on perceived ease of use has an important and positive impact on attitude, hypothesis H2 was acknowledged. According to Weng et al. (2018), there is a solid effect on attitude towards online learning acceptance. This point concluded that there is no refusal among respondents because the users can use it. Next, attitude has a significant relationship with the behavioural intention of using online learning; as a result, hypothesis $\mathrm{H} 3$ was accepted. Behavioural intention affects the attitude towards using which refers to a personal feeling of a person to perform positive and negative habits. It can be concluded that the success of online learning acceptance may be determined by users' confidence from the intention to use it. The effect of the influence of behavioural intention on actual use was positively significant; therefore, hypothesis $\mathrm{H} 4$ was accepted. This is associated with previous findings by Wang et al (2019) who found that behavioural intention has a strong relationship with actual use. The results show that the actual use of online learning significantly influences students' emotional well-being, hence, hypothesis $\mathrm{H} 5$ also was accepted. The study also confirmed that there is a significant relationship between the actual use of online learning and emotional well-being which supported hypothesis H6. This result also suggests that online learning has a substantial effect on the emotional well-being for both introverts and extroverts, with a greater effect on extroverts than introverts (even though both are significant). Thus, H7 was supported. The findings of this study can help undergraduates recognise the factors that can affect their emotional well-being, particularly when coping with online learning which can be difficult. This research will help lecturers and teachers understand how to deal with undergraduates' emotional well-being so that the teaching and learning process can run smoothly.

This study will provide a new contribution of knowledge by introducing two new constructs, namely personality traits and emotional well-being as the extension of the existing TAM Model. This is important to create awareness among lecturers and universities management towards the special needs and attention of students who are having a negative impact on online learning. This is because different personality traits will require varying levels of attention and care, particularly introverted personalities, who are likely to be influenced by their emotional well-being as a result of the use of online learning. The findings of this study can also help policymakers, particularly the Ministry of Higher Education, develop a comprehensive policy that can improve the tertiary education system by focusing on the third Sustainable Development Goal (SDG) of creating good health and well-being, which can be implemented in both public and private higher education institutions. 
DEVELOPMENT

Vol. 11, No. 1, 2022, E-ISSN: 2226-6348 @ 2022 HRMARS

\section{Suggestion for Future Research}

There are several limitations identified in this study. First, the response gathered from the respondents of this study may or may not be generalized to other public or private higher education institutions in Malaysia since they consisted only of the students from Universiti Teknologi MARA (UiTM) Pahang Campus. This is due to the different styles of teaching, syllabus, number of subjects taken per semester, online platform chose by the lecturers etc. This research also did not take into consideration the type of learning and meeting platforms used by the lecturers in delivering the content of the syllabus. Thus, future research should include students from other UiTM branches and higher education institutions, from private or public universities, so that the results produced are generalizable. Second, this study investigates the moderating effect of personality traits between the actual use of online learning towards emotional well-being and did not consider any other external factors that could affect the students' responses in this study such as the students' locality, courses taken, level of education, the situation at home, and their Internet connection. The incidents of the current pandemic, COVID-19, may somehow affect the students' response. Therefore, future research could envision all these issues that might provide different results.

\section{Acknowledgements}

This paper is financially supported by the Special Sustainable Fund Research Grant 2020 (Geran Penyelidikan Dana Lestari Khas 2020) with the project code: 600-UiTMKPH (PJI.5/2/4/9)/ DLK (009/2020) from Universiti Teknologi MARA Pahang.

\section{References}

Almaiah, M. A., \& Alyoussef, I. Y. (2019). Analysis of the Effect of Course Design, Course Content Support, Course Assessment and Instructor Characteristics on the Actual Use of E-Learning System. IEE Access, 7. 171907-171922.

Alsabawy, A. Y., Cater-Steel, A., \& Soar, J. (2016). Determinants of perceived usefulness of elearning systems. Computers in Human Behavior, 64 (2016), 843-858. https://doi.org/10.1016/j.chb.2016.07.065

Bhagat, K. K., Wu, L. Y., \& Chang, C. Y. (2019). The impact of personality on students' perceptions towards online learning. Australasian Journal of Educational Technology, 35(4), 98-108. https://doi.org/10.14742/ajet.4162

Davis, F. D. (1989). Perceived usefulness, perceived ease of use, and user acceptance of information technology. MIS Quarterly, 13(3), 319-340.

Farhan, W., Razmak, J., Demers, S., \& Laflamme, S. (2019). E-learning systems versus instructional communication tools: Developing and testing a new e-learning user interface from the perspectives of teachers and students. Technology in Society, 59 (2019), 101192. https://doi.org/10.1016/j.techsoc.2019.101192

Hussein, Z. (2017). Leading to Intention: The Role of Attitude in Relation to Technology Acceptance Model in E-Learning. Procedia Computer Science, 105 (2017), 159 - 164.

Kerzic, D., Tomazevic, N., Aristovnik, A., \& Umek, L. (2019). Exploring critical factors of the perceived usefulness of blended learning for higher education students. PLOS ONE, 14(11), e0223767. https://doi.org/10.1371/journal.pone.0223767

Menon, U. K., Ramachandran, R., Gopalakrishnan, S., Unni, S. N., Radhakrishnan, N., Baby, P., \& Sasidharan, A. (2021). Perceptions of undergraduate medical students regarding institutional online teaching-learning programme. Medical Journal Armed Forced India, 77, 227-233. https://doi.org/10.1016/j.mjafi.2021.01.006 
Peytcheva-Forsyth, R., Yovkova, B., \& Aleksieva, L. (2018). Factors affecting students' attitudes towards online learning - The case of Sofia University. AIP Conference Proceedings 2048, 020025 (2018); https://doi.org/10.1063/1.5082043

Porter, C. E., \& Donthu, N. (2006). Using the technology acceptance model to explain how attitudes determine Internet usage: The role of perceived access barriers and demographics. Journal of Business Research, 59 (2006), 999-1007. doi:10.1016/j.jbusres.2006.06.003

Rahiem, M. D. H. (2021). Indonesian University Students' Likes and Dislikes about Emergency Remote Learning during the COVID-19 Pandemic. Asian Journal of University Education, 17(1), 1-18.

Saadé, R. G., Kira, D., Mak, T., \& Nebebe, F. (2017). Anxiety and Performance in Online Learning. Proceedings of the Informing Science and Information Technology Education Conference, Vietnam, pp. 147-157. Santa Rosa, CA: Informing Science Institute. http://www.informingscience.org/Publications/3736

Solangi, Z. A., Al Shahrani, F., \& Pandhiani, S. M. (2018). Factors affecting successful implementation of e-learning: Study of colleges and institutes sector RCJ Saudi Arabia. International Journal of Emerging Technologies in Learning, 13(6), 223-230. https://doi.org/10.3991/ijet.v13i06.8537

Wang, L. Y. K., Lew, S. L., Lau, S. H., \& Leow, M. C. (2019). Usability factors predicting continuance of intention to use cloud e-learning application. Heliyon, 5, e01788. https://doi.org/10.1016/j.heliyon.2019.e01788

Weng, F., Yang, R., Ho, H., \& Su, H. (2018). A TAM-Based Study of the Attitude towards Use Intention of Multimedia among School Teachers. Appl. Syst. Innov. 1(36), doi:10.3390/asi1030036.

Yawson, D. E., \& Yamoah, F. A. (2020). Understanding satisfaction essentials of E-learning in higher education: A multi-generational cohort perspective. Heliyon, 6 (2020) e05519. https://doi.org/10.1016/j.heliyon.2020.e05519

$\mathrm{Yu}, \mathrm{Z}$. (2021). The effects of gender, educational level, and personality on online learning outcomes during the COVID-19 pandemic. Int J Educ Technol High Educ, 18(14), 1-17. https://doi.org/10.1186/s41239-021-00252-3 